\title{
VAD KAN VI LÄRA OSS OM TYSTNAD GENOM EN NÄRLÄSNING MED MARCEL MAUSS?
}

\author{
TORBJÖRN FRIBERG
}

I sin klassiska bok Gåvan (1925) visade Marcel Mauss på gåvoutbytets moraliska struktur om förpliktelsen att ge, att ta emot samt återgälda. Det teoretiska antagandet är att när en person ger en gåva kommer mottagaren att stå i skuld till givaren. Denna skuld är något som dock senare infrias om gåvan återgäldas med en annan gåva. I detta sammanhang ställde Mauss följande frågor: ,Vad är principen när den mottagna gåvan skall återgäldas i primitiva eller föråldrade samhällen? Vad är det för inneboende och urgammal kraft som sporrar mottagaren att åstadkomma en gengåva?“ (Mauss 1972 [1925]) I sitt svar gör Mauss ingen åtskillnad mellan ting och person, vilket leder till att han kan hävda att det finns en inneboende kraft ( $h a u$ ) i gåvan som strävar tillbaks till givaren. Det är sålunda denna kraft som utgör grunden för gengåvan då tingen betraktas som delar av personen. Han skriver:

Mycket av vår vardagsmoral upptas av frågan om plikt och spontanitet av givandet. Lyckligtvis uttrycks ännu inte allt i försäljnings- och köptermer. Tingen har känslomässiga värden såväl som materiella, och faktiskt har de i vissa fall helt känslomässiga värden. Vår moral är inte helt kommersiell (Mauss 1972:85).

Slutsatsen, att det finns en historisk ursprunglig koppling mellan det materiella och känslomässiga i gåvan, kom Mauss fram till efter att ha behandlat en stor mängd historiskt och etnografiskt material. I en närläsning blir det snabbt klart att Mauss till stora delar använde sig av etnografiskt materialet kring Nordvästamerika och Melanesien för att kunna teoretisera gåvan och gengåvan. Som tidigare antropologer har uttryckt utgör både den nordvästamerikanska potlatchen och det melanesiska kulasystemet centrala delar i Mauss utveckling av gåvoteorin (Fournier 2005:238-45; Graeber 2001:164; Hart 2007:8). Härav följer att föreliggande studie har fokus på Mauss användning av Franz Boas (1858-1942) beskrivningar om nordvästamerikanska indianer, samt Bronislaw Malinowskis 
(1884-1942) redogörelser av Melanesien. Detta i linje med Mauss konstruktion av gåvoteorin. Med detta vill jag framhålla att artikeln inte gör några anspråk på att vara en heltäckande redogörelse för Mauss konstruktion av gåvoteorin.

Mot bakgrund av den ,nya postmoderna kritik“, som den antropologiska disciplinen stod inför under 1980-talet, växte det fram en „motkritik“ som kan exemplifieras med hjälp av Localizing Strategies: The Regionalization of Ethnographic Accounts (1990). Richard Fardon, redaktör till antologin, skriver att den moderna antropologin bygger på tre element: fältarbete (deltagande observation), teoretiska argument och skrivande av monografier. Malinowski och Boas betraktas, som bekant, som urtyperna då de behärskade samtliga element. I detta sammanhang menar Fardon att samtidens antropologer har ett ambivalent förhållningssätt gentemot de tidigare antropologerna. Samtidigt som vi vurmar för den äldre generationens etnografiska beskrivningar riktar vi skarp kritik mot deras teoretiska perspektiv. På ett teoretiskt plan ser vi Malinowski och Boas som „barn av sin tid“ medan samma antropologer, på ett etnografiskt beskrivande plan, betraktas som ständigt relevanta. Detta, menar Fardon, bottnar i en föreställning att teori är något flyktigt och föränderligt medan etnografiska beskrivningar är disciplinens fasta egendom (Fardon 1990:1-2). Fältarbetet förefaller vara tidslöst och ahistoriskt medan teorin definitivt kan kritiseras utefter idéhistoriska studier. Med detta sagt har vi, enligt Fardon, en uppfattning att teorin inte bestämmer etnografin eller det etnografiska skrivandet. Antropologer kritiserar vanligtvis icke-antropologer (missionärer, upptäcktsresande och kolonialister) genom påståenden att de har en klar och given teoretisk förförståelse i sina beskrivningar av „den andre“. Denna förförståelse gäller emellertid inte för den professionellt tränade antropologen: han eller hon bygger ju sina teorier utifrån fälterfarenheter som innebär en längre tids deltagande och observation bland/av „de andra“. Med andra ord, teori bestämmer inte den etnografiska berättelsen då denna baseras på erfarenheter (Fardon 1990:3). Antropologer instämmer ofta med „teoretiska förbättringar“ under det att „,etnografiska utvecklingar“ förefaller vara något nästintill omöjligt. När det kommer till etnografiska objekt bygger antropologerna flitigt vidare på tidigare pionjärarbeten genom att fylla i de „luckor“ som lämnats kvar. Härmed understryker Fardon att den etnografiska praktiken uppfattas vara av kumulativ karaktär. Teorier kan förkastas genom att hävda att de är felaktiga medan etnografin har ett slags egenvärde som medför att den kan återanalyseras i all oändlighet (op.cit.4). Detta är något som de ,nya kritikerna“ (bl.a. James Clifford, George Marcus och Steven Tylor) har missat i sin kritik av det etnografiska skrivandet. Vad de nya kritikerna har gemensamt är, enligt Fardon, att de drar lärdom från äldre etnografers beskrivningar av , de andra“. Även om Fardon inte direkt misstycker med de nya kritikernas övergri- 
pande insikter understryker han dock att de har missat den etnografiska praktikens kontext. Snarare än ta bort den gamla ordningen har de nya kritikerna förstärkt den. Fardon kritiserar sålunda de nya kritikerna för att de genom närläsningar av gamla konventioner uppmanar till en ny radikalt förändrad praktik inom den antropologiska disciplinen, vilket leder till en ohållbar och ambivalent situation (op.cit.4-5). I ett försök att komma runt denna ambivalens gör Fardon en poäng av att vi behöver bättre kunskap om de lokala strategier som antropologer använder sig av i en etnografisk kontext. Konstruktionen av etnografiska erfarenheter och beskrivningar bör betraktas som ett relationellt fenomen inom en historisk och regional kontext (op.cit.19). Att etnografiska beskrivningar omarbetas på olika sätt, utifrån lokala strategier med specifika teoretiska utgångspunkter, är något som vi antropologer ofta håller tyst om (op.cit.22).

De lokala strategier som Fardon diskuterar handlar övergripande om den etnografiska praktikens kontext, dvs. hur etnografiska erfarenheter och beskrivningar, som relationella fenomen, hänger samman med historiska och regionala villkor. För att undvika missförstånd vill jag här understryka att begreppsanvändningen i föreliggande artikel dock ter sig något annorlunda än Fardons. Eftersom Mauss själv inte befann sig i de etnografiska regionerna, som grund för specifika erfarenheter som senare tar sig uttryck i den etnografiska beskrivningen, sammankopplas de ,lokala strategierna“ här istället med det intellektuella och politiska klimatet i Frankrike under 1920-talet. Gåvan bygger inte, som beskrivits ovan, på den moderna antropologins tre element. Även om gåvoteorin understöds med hjälp av etnografiska beskrivningar gjorde Mauss själv inget fältarbete.

Artikelns ändamål handlar emellertid inte om att kritisera Mauss och hans behandling av det etnografiska materialet i samband med konstruktionen av gåvoteorin. Syftet med föreliggande artikel är att diskutera begreppsligheten av tystnad, utefter en närläsning med Gåvan och tillhörande referenslitteratur. Den metod som ligger till grund för denna sorts närläsning hämtar inspiration från filosofen Gilles Deleuzes tillvägagångssätt (Deleuze 2004). Snarare än att peka på misstag och felaktigheter i den etnografiska beskrivningen vill jag sålunda försöka producera några nya tankar om tystnad. Detta innebär en strävan med hellre än mot. Istället för att kritisera Mauss, såsom det tidigare gjorts av en mängd eminenta antropologer (se exempelvis Carrier 1991; Godelier 1999; Lévi-Strauss 1987; Liep 2009; Parry 1986; Testart 1998), handlar det här om ett experiment att bringa resonans med tystnaden.

Inledningsvis studeras Mauss användning av Boas etnografiska beskrivningar, där det framgår att den senare antropologens skrifter är idealiska för en återanalys. Detta innebär att Mauss i rollen som skrivbordsetnograf på nytt analyserar och till viss del omformar materialet, vilket leder till vissa diffusa och oklara 
resonemang. Bland annat tillskriver Mauss bytesföremål en personlighet - ett resonemang som inte finns att hitta i de ursprungliga texterna. Den andra delen har fokus på Mauss tillämpning av Malinowskis etnografiska beskrivningar. Analysen här handlar om hur Mauss till en början samspelar med Malinowskis antagande att kulamyterna berättar något om den reella världen. Detta övergår senare till en diskussion om hur Mauss intar en mer polemisk position gentemot Malinowskis argument om „,den rena gåvan“. Detta är en väsentligt retoriskstrategisk funktion i framställningen av gåvoteorin. Den tredje delen återknyter till Fardons tanke att inplacera den etnografiska beskrivningen i en intellektuell och politisk kontext, vilket medför en bättre förståelse av de lokala strategierna (tystnad). Efter en kortare sammanfattning övergår slutsatsen i en diskussion av tystnadens inneboende ambivalens (tvivel och förtroende) i förhållande till den etnografiska beskrivningen.

\section{Boas betydelse för Mauss analys kring gåvogivningen}

Mauss som övervägande utgår från Boas etnografiska beskrivningar om potlatch (rituell gåvofest bland nordvästkustindianerna) har inte lämnat något åt slumpen då han ofta resonerar kring små detaljer med en imponerande precision. Han ger intryck av ha läst det mesta om indianerna på nordvästkusten i USA som hade någon koppling till hans resonemang angående gåvogivningen. Resultatet blev en imponerande analys som Mauss slutligen presenterade för omvärlden. Frågan här är hur han egentligen använde sig av Boas etnografiska beskrivningar. Det verkar inte som om det var en ren tillfällighet att Mauss delvis använde sig av Boas material med tanke på att den senare antropologen ägnade mycket tid åt olika institutioner bland de nordvästamerikanska indianerna. Boas skrev nämligen mer än 10.000 sidor, under en period av nästan sextio år, om både myter, danser, sånger, familjehistorier, ritualer och konst (Codere 1959). Då Boas opponerade sig mot linjär evolutionism, samtidigt som han underströk att varje kultur var säregen och hade sina speciella förutsättningar, brukar hans publikationer inordnas under rubriken „historisk partikularism“. Det är utifrån denna idéströmning som Boas framhöll att varje kultur hade genomlöpt sin egen utveckling i samband med kontakt och spridning som verksamma faktorer. Han accentuerade att de kulturella slutprodukterna, till skillnad från evolutionisternas parallellism, var unika företeelser (Trigger 1993:185f.). Boas bestred, först och främst, de evolutionistiska tankarna och menade att begrepp som „,vildar“, „,barbarer“ och „,civiliserade“ enbart är typologiska tankemodeller. Enligt honom fanns det ingen klar utstakad evolutionistisk utvecklingslinje, där människan måste passera varje stadium för att slutligen uppnå det västerländska samhället (Lindberg 1997b:263). 


\section{Objektiv rådata och filologiska möjligheter}

Boas menade att den antropologiska vetenskapen hade till uppgift att studera sociala fenomen. Dessa fenomen skulle följaktligen delas upp i tre grupper: 1) människans fysiska byggnad; 2) språk; och 3) seder och trosföreställningar. Metoden som skulle användas i ovanstående gruppering skulle utgå från ett induktivt arbetssätt. Alltså, för att kunna få full förståelse för en kultur krävs det en rekonstruktion av den historiska utvecklingen till den tid då forskaren studerar den (Lindberg 1997a:6, 62). Som andra samhällsforskare har understrukit öppnade Boas historiebeskrivande perspektiv upp för andra antropologer att använda sig av hans etnografiska material (Smith 1959). Det vill säga att det som är generellt explicit och utförligt beskrivet, såsom t.ex. ett utbyte av gåvor mellan två parter, kan lättare behandlas på ett analytiskt sätt än om det redan är av en hypotetisk karaktär. Det går att beskåda hur Boas infallsvinkel till fältarbetet var objektiv i den bemärkelsen att hans material uppfattades som „rådata“. Kritikerna har ofta anklagat Boas för att enbart ha samlat in material utan någon som helst ingående analys av data. Enligt kritikerna handlade det enbart om ett uppvisande av materialet utan någon vetenskaplig efterforskning (Lindberg 1997a:59). Marian W. Smith skriver att när Boas etnografiska beskrivningar publicerades kunde dess slutsatser kontrolleras samtidigt som materialet låg öppet för andra forskares analyser: „Texterna var objektiva i den meningen att de alltid var tillgängliga för återanalyser" (Smith 1959:51).

Styrkan i Boas material ligger i att informationen är insamlad och presenterad på ett sätt där omgivningen har en så liten medverkan som möjligt. Detta gör han bland annat genom att framställa empirin genom indianernas egna villkor och begrepp. Exempelvis i Annual Report of the Bureau of American Ethnology 191314 står det att läsa att materialet till texten hade samlats in och sammanställts av Georg Hunt som var „halvblod“ kwakiutl. Boas skriver att Hunt ,är ansvarig för riktigheten, äktheten och innehållets karaktär i artikeln“ (Boas 1913-1914:39). Genom att använda sig (få hjälp) av det folk som han studerade har han fått ett perspektiv som klart minimerar etnografens auktoritära ställning (Smith 1959: 53). Frågan här är om Mauss medvetet valde Boas etnografiska beskrivningar på grund av det låg öppet för en återanalys? Det svar som ligger närmast är Mauss förklaring i metodavsnittet där han skriver: „Eftersom vi sysslar med ord och deras betydelse har vi naturligtvis bara valt områden där vi har haft möjlighet till närmare studier av samhällsfunktionerna genom dokumentation och filologiska arbeten“ (Mauss 1972:18). Här förefaller det som om Boas beskrivningar, baserade på „den andres“ föreställningar och begrepp, passade Mauss filologiska förhållningssätt. 


\section{Heder och ära}

I en diskussion om heder och ära menar Mauss att begreppen framstår tydligare $\mathrm{i}$ Nordvästamerika än om man jämför med Melanesien och Polynesien. För att styrka sitt påstående citerar han Boas rapporter , $12^{\text {th }}$ Report" och , $7^{\text {th }}$ Report" $i$ Report of the British Association for the Advancement of Science (Mauss 1972:53; fotnot 112). Kort sammanfattat menar Boas här att det ,ekonomiska“ systemet (potlatch) till stor del är baserat på kredit och att transaktionen genomförs offentligt för att ge säkerhet för återgäldandet. Styrmekanismerna i det „ekonomiska“ systemet är sålunda heder och ära eftersom det inte finns några lagar. I sin kommentar till detta påstående skriver Mauss följande: „Genom att ersätta Boas termer med ord som 'gåvor som ges och ges tillbaka' [vilket Boas till sist gör] ser man tydligt kreditens funktion i potlatch“" (op.cit.136). Vilka termer det är frågan om nämns inte alls utan läsaren får själv lista ut att Mauss (förmodligen) menar Boas begrepp „ekonomi“. Mot denna bakgrund förefaller det som om Mauss begreppsersättning ligger till grund för att stärka hypotesen att gåvor i sin principiella form handlar om att ge och återgälda. Det är bland annat i detta resonemang som Mauss visar på den reciprocitet som finns mellan två eller fler ,parter“.

\section{Bytesföremålens kraft}

När det kommer till Mauss resonemang om bytesföremålens kraft (op.cit.61) görs detta med hjälp av bl.a. Boas' ,5 ${ }^{\text {th }}$ Report“ (Boas 1889:839). I detta sammanhang menar Mauss att föremål av en viss kategori som värdefulla familjeägodelar, talismaner, dekorerade kopparplåtar, skinnfiltar och broderade tyger, alla innefattar en kraft som tvingar dem att cirkulera mellan olika parter. Överlåtandet av dessa föremål är inte för evigt utan det kan snarare benämnas som ett lån. Mauss som gör en anslående analys av en stor mängd etnografiskt material kommer fram till slutsatsen att dessa föremål ,är alla personligheter“ (Mauss 1972:63). Med referens till Boas skriver Mauss att bl.a. abalone-skalen, som är chinookordet för de stora haliotisskalen, äger en personlighet (op.cit.62). I en närmare jämförelse med Boas text finner läsaren emellertid inget belägg för att föremålet äger en personlighet (Boas 1889:839). I detta sammanhang verkar det som om Mauss har mer (tyst) kunskap om det specifika föremålet än vad han tillkännager, vilket gör att hans texter blir aningen svåröverskådliga. Detta är något hans vän Henri Hubert även påpekat i samband med sin kritiska granskning av manuset till Gåvan (Fournier 2005:244). Som läsare blir det svårt att följa hans slutledningar ifrån de källor som ligger till grund för utvecklingen av gåvoteorin. Inte sällan måste läsaren själv vara med och tolka i samband med Mauss allehanda referenser till de etnografiska texterna. 


\section{Rituella felsteg och sona}

Vidare refererar Mauss till „Duncan, i Mayne, Four Years in British Columbia“, när han diskuterar tsimshian, som genom ett rituellt felsteg sonar genom att ge en potlatch (Mauss 1972:142). Här har Mauss utelämnat Boas material om tsimshian, som han tidigare har använt sig av. Vid en närmare granskning finner vi att Mauss referens till Duncans argument liknar Boas resonemang om Tsimshian Mythology (Boas 1909-1910:383). Mauss refererar alltså till en helt annan källa än han tidigare använt sig av. Vad detta beror på är svårt att avgöra, men ett antagande kan vara att Mauss sökte ytterligare styrka i sin analys. Detta är självklart en fördel på en vetenskaplig nivå, dvs. söka efter så många oberoende källor som möjligt. Men även om hans analys är av hög standard blir det svårt att förstå varför han har uteslutit Boas text i denna kontext. Längre fram texten går det emellertid att se hur Mauss ännu en gång refererar till Boas material , ,5 $5^{\text {th }}$ Report"“ (Boas 1889: 838). Detta gör han i samband med diskussionen kring ett felsteg som begås av en hövding som kan göra rätt för sig genom att ge en potlatch. Han skriver: „Om en hövding vill ha en anledning till att ge en potlatch, kan han skicka sin hustru till hennes far som en förevändning“" (Mauss 1972:143). Som läsare i detta sammanhang är det lätt att tro att detta påstående endast gäller hövdingen. Vid en närmare betraktelse av Boas text visar det sig emellertid att så inte är fallet. Om man som läsare följer Boas skrift från början går det att urskilja att denna text generellt handlar om kwakiutlsamhällets regler om giftermål i helhet, och inte enbart regler för hövdingar att följa (Boas 1889:838). Med detta förefaller det som om Mauss håller tyst om att det samma gäller för samtliga stammedlemmar.

\section{Malinowskis „förarbete“ till Mauss utveckling av gåvoteori}

Mauss framhåller att Melanesien i hög grad har utvecklat eller bibehållit alla former av gåvoutbyte (Mauss 1972:35). Efter en oansenlig behandling av Maurice Leenhardts dokument, „La Monnaie Néo-Calédonienne“ i Revue d'Ethographie, övergår Mauss till andra änden av den melanesiska världen. Här behandlas invånarna på Trobrianderna med hjälp av Malinowskis berömda arbete Argonauts of the Western Pacific. Malinowskis arbete är, enligt Mauss, av hög beskaffenhet och går in under samma ämne som han själv är intresserad av, dvs. system av handel (kula). Mauss skriver att Malinowskis arbete är ,bland det bästa som skrivits i deskriptiv sociologi“" (op.cit.37). Kunskap om Trobrianderna erhöll Mauss alltså genom Malinowskis beskrivningar varifrån han sedan prövade sina hypoteser. För att Mauss skulle kunna forma relevanta hypoteser bör han ha krävt en teoretisk medvetenhet där samhället kan iakttagas från olika vinklar. Att Malinowski sammankopplas med funktionalism är för de flesta antropologer en självklarhet, 
då han i sin bok Argonauts of the Western Pacific tog hänsyn till hur „kulturen“ fungerade på ett sammanhängande sätt. I samband med detta tillvägagångssätt märks det en Durkheiminspirerad Malinowski (Trigger 1993:292f.). Här skall det dock understrykas att även om Mauss verkade nöjd med Malinowskis arbete påtalade han att denne antropolog överskattade nyhetsvärdet av sin beskrivning av kula (Mauss 1972:124). Här följer att Mauss likställer kula med den amerikanska potlatchen då han skriver att: „Kula är ett slags storslagen potlatch“ (op.cit.37). Mauss verkar mena att de är likartade institutioner även om handelsvägarna skiljer sig åt. Att betrakta kula och potlatch som en och samma typ av institution förefaller vara en styrka i Mauss konstruktion av den universella gåvoteorin.

\section{Kulamyter och den reella världen}

Mauss bygger sitt resonemang på Malinowskis beskrivningar som bland annat består av olika kulamyter. Exempel på detta finner läsaren när Mauss refererar (op.cit.125) till sidan 313-15 i Argonauts of the Western Pacific. Här utgår Mauss från att den mytologiska världen är tätt integrerad med den reella världen. Antagandet att myterna berättar en hel del om kulturens olika institutioner är något som Malinowski länge har påpekat. Malinowski skriver om att myten (som Mauss använder sig av) verkligen är en informativ källa då den innefattar en många viktiga detaljer. Myten innehåller sålunda bred kunskap om det sociala, tekniska och organisatoriska vad gäller kanottillverkning, segling och kula (Malinowski 1922:318). Utifrån denna myt gör Malinowski olika analogier med det reella livet. Detta sker på ett sätt där myten hjälper etnografen att bättre förstå olika institutioner. Här kan vi se hur Mauss och Malinowski samspelar då de båda hämtar kunskap från myternas värld för att bättre kunna förstå den reella världen. Både Malinowski och Mauss verkar ha varit medvetna om att myter har en stor betydelse i samband med förståelse för ,de andra“. Båda sätter myterna i samhällets kontext. Deras inställning till myter kan sägas vara funktionalistisk i en Durkheimisk anda där myterna är en funktionell del av den sociala helheten. Även om Mauss är medveten om myternas betydelse kan vi dock ställa honom i opposition till Malinowski då han använder sig av myterna som text utan tillgång till den levande kulturen genom deltagande observation. Mauss verkar snarare använda sig av myterna för att finna ,,allmänna lagar“ som berättar något om hur hela gåvoprocessen regleras i kula (Mauss 1972:35).

\section{Utilitarism och den rena gåvan}

I sina „politiska och ekonomiska“ slutsatser kommer Mauss fram till att den gåvoutbytesekonomi han diskuterat genomgående inte passar ihop med utilitarism. Att människor i de ,primitiva“" samhällena först och främst skulle bestämma vad 
som är gott för alla människor och därefter handla efter detta stämmer inte. Mauss hävdar att det ekonomiska handlandet är en komplex situation som varken är helt egennyttigt eller utilitaristisk utan snarare en hybrid. Han kritiserar Malinowskis klassificering av olika transaktioner på Trobrianderna allteftersom en klassifikation utifrån egennyttigt (byteshandel) eller oegennyttigt (ren gåva) är ett ohållbart koncept (op.cit.94). Vid första anblicken verkar detta vara plausibelt då Mauss refererar till Malinowski, men genom en djupare inblick i detta material går det att se hur Malinowski faktiskt inte påstår att gränserna är helt fasta mellan de olika transaktionerna. Malinowski menar nämligen att det är omöjligt att exakt dra en linje mellan handel och utbyte av gåvor (Malinowski 1922:176-8). Malinowski utgår från en ren gåva som sedan övergår till olika former av utbyte som slutligen avslutas i ren byteshandel. Den ,rena gåvan“ är, enligt Malinowski, den mellan äkta makar, som skall förstås som ,en handling, där en individ ger ett objekt eller utför en tjänst utan att förvänta sig eller få något tillbaka“"(op.cit.177). Att det på något vis skulle förekomma en oegennyttig transaktion mellan makarna stämmer inte enligt Mauss. Här, i detta skede, gör Mauss en jämförelse i Malinowskis arbete, dvs. en gåva mellan makarna och en gåva mellan ogift man och kvinna. Gåvan, mapula, som är en slags ersättning för bl.a. sexuella tjänster mellan man och kvinna är enligt Mauss den samma som den ,rena gåvan“ mellan makarna. Det handlar om en slags betalning, en ersättning precis som en betalning till en hövding. Mauss skriver: ,Således är dessa gåvor i grunden inte spontana och alltså inte heller verkligt oegennyttiga. De är till största delen motprestationer, som görs inte endast för att betala varor eller tjänster, utan också för att upprätthålla en fördelaktig allians som det vore oklokt att förkasta“ (Mauss 1972:94). Vad Mauss är tyst om i detta förlopp är Malinowskis kriterier för de två olika gåvorna. Malinowski menar att de är helt olika eftersom de mellan make och hustru är tillfälliga gåvor inom en fast relation, medan de övriga är definitiva betalningar för tjänster vid speciella tillfällen (Malinowski 1922:179). Malinowski skiljer således bl.a. gåvor beroende på om de utgör en permanent eller tillfällig relation. I Mauss jämförande utelämnas även andra faktorer som spelar in i Malinowskis klassifikationsmodell. Malinowski skriver att den bakomliggande psykologin handlar om att ,en man är emotionellt bunden till sin fru [...] och uttrycker dessa känslor med gåvor“ (ibid.). Enligt Malinowski sker ett överlämnande av en oegennyttig gåva i samband med ett uttryckande av känslor istället för ren vinnings skull. Att några känslor överhuvudtaget tas upp av Mauss finner vi inga spår av. Det verkar nästan som om han ibland använder sig av en alltför kraftig generalisering som helt utelämnar individen och dess emotionella aspekter i samband med gåvogivningen. ${ }^{1}$ Intressant är att Mauss argument kan jämföras med en filosofisk diskussion, dvs. om utilitarism egentligen existerar. Detta är precis vad han gör då 
han menar att egennyttan och oegennyttan är en hybrid. Alltså finns inte en ,ren gåva“", dvs. en oegennyttig handling. Alla relationer handlar, enligt Mauss, om prestationer och motprestationer oavsett kontext. I Brott och bruk $i$ ett primitivt samhälle skriver emellertid Malinowski följande:

Jämför även med den träffande kritik av mitt uttryck 'ren gåva' och vad det innebär som framförts av Marcel Mauss [...] Jag hade skrivit ovanstående avsnitt, innan jag såg Mauss anmärkningar, som $i$ allt väsentligt stämmer med mina egna. En fältforskare känner tillfredsställelse, när han finner, att han redovisat sina iakttagelser så väl, att andra haft möjlighet att utifrån hans eget material, förkasta de slutsatser han dragit. Det är ännu mer tillfredsställande för mig, att mitt mer mogna omdöme helt oberoende lett mig till samma resultat som de som min framstående vän Marcel Mauss uppnått (Malinowski 1967:52).

Med dessa rader ger alltså Malinowski Mauss rätt i sin kritik av den „rena gåvan“.

\section{Den etnografiska beskrivningens intellektuella och politiska kon- text}

Om vi vidare skall försöka förstå Mauss lokala strategier, såsom de beskrivits ovan, bör vi följa Fardons uppmaning att inplacera den etnografiska beskrivningen i ett bredare sammanhang.

I Edward Evan Evans-Pritchards inledning till The Gift från 1969 står det att läsa att Mauss trängde djupt in i det etnografiska materialet samtidigt som han tog sig an allt tillgängligt lingvistiskt material. Då Mauss var tränad i sociologisk metod likställer Evans-Pritchard honom med en antropolog på fältarbete, vilket innebär att han uppfattas både kunna observera och erfara det sociala livet bland „de andra“. Med detta följer att: „Vi socialantropologer betraktar därför honom som en av oss“ (Evans-Pritchard 1967:viii). Att Mauss skulle arbeta på samma sätt som en antropolog ute i fält, såsom Evans-Pritchards beskriver det, är dock svårt att föreställa sig då en skrivbordsetnograf inte kan erfara eller observera det sociala livets lokala villkor i realtid eller med sina mänskliga sinnen. Vanligt är att en fältarbetare och en skrivbordsetnograf brukar ha olika förhållningssätt till relationen mellan teori och empiri. Medan den förstnämnda brukar utgå från ett abduktivt förhållningssätt, där han eller hon alternerar mellan empiri och teori i sin hypotesuppbyggnad, har den senare vanligtvis en deduktiv synsätt (jfr. Agar 1986). Mitt argument, utifrån ovanstående exempel, är att Mauss i rollen som en skrivbordsetnograf utgår från en teoretisk föreställning att samhällets fundament utgörs av solidaritet och reciprocitet (jfr. Fournier 2005:238f.). Detta innebär att de etnografiska exemplen, i Mauss beskrivningar, många gånger retoriskt verkar 
illustrera eller fylla den redan på förhand utstakade teorin. Utgångspunkten är sålunda förankrad i en generell regel som förutsätter vad som skall förklaras, där empirin uppnår en slags tomhet som har sin funktion i att tillfredsställa den teoretiska utgångspunkten. Att Mauss medvetet utesluter olika motsägelser i materialet går att finna i kapitel två där han bland annat skriver:

[F]örekomsten av ett slags potlatch hos pygméerna är egendomligt, och inte mindre förbryllande är spåren av en indoeuropeisk potlatch. Vi avstår från att göra några betraktelser över det sätt som institutionen spridits på. Det skulle vara både naivt och farligt att ge sig in på spekulationer om lån eller självständig utveckling (Mauss 1972:34).

Utelämnandet av det etnografiska materialet görs här (förmodligen) i deduktivt syfte. I citatet ovan handlar det om en förklaring till varför detta material (potlatch hos pygméerna och indoeuropeisk potlatch) inte tas upp i samband med gåvogivningen och detta på ett vetenskapligt sätt där han visar på sin metod. Avståndstagandet visar dock på att Mauss, med sin deduktiva ansats, får svårt att ta sig an spekulationer då detta kan spränga det teoretiska utgångsläget. Frågan här blir: vad har Mauss att deducera från? För att kunna besvara denna fråga bör vi, kort, vända oss till hans förhållningssätt gentemot samtida intellektuella diskussioner samt förstå hans argument i ljuset av hans politiska engagemang som socialist.

I David Graebers (2001) excellenta nyläsning av Gåvan blir det klart för läsaren att Mauss bygger vidare på den intellektuella tradition som berörde de sociala förändringarna under artonhundratalet: individualismens uppgång, den religiösa solidaritetens förfall, den traditionella auktoritetens försvinnande och marknadens framväxt som medium för mänskliga relationer. I detta sammanhang förefaller Gåvan vara ett sökande efter det sociala kontraktets ursprung (Graeber 2001:152). Detta överensstämmer väl med Marshall Sahlins påstående att Mauss sökande är en förlängning av filosofen Thomas Hobbes (1588-1679) projekt. Hobbes utgick nämligen från att det sociala kontraktet i samhället utgör grunden för undvikandet av att „allas krig mot varandra“"(Sahlins 1984:169f.). Om vi återknyter till Graeber finner vi här ett intellektuellt klimat där ,gåvans ursprung" blir till en viktig fråga. I sitt sökande tar Mauss ställning mot de samtida teoretikerna som hävdade att det sociala kontraktet har uppkommit i samband med statens monopol att skapa fria kontrakt mellan individer. Graeber menar att ekonomernas arbetshypotes var att den ursprungliga formen av utbyte var byteshandel som motiverades av materiellt egenintresse: två människor möts och enas om att byta något man behöver. När väl bytet är genomfört är det över och de två parterna har inte längre något ytterligare att göra med varandra. Vad Mauss menade är att om människan endast agerar i ekonomiskt självintresse, blott är in- 
tresserad av materiell vinning, då skulle mottagaren behålla varorna utan någon eftertanke på en radikal motgåva (Graeber 2001:153f.). Genom Gåvan utmanar alltså Mauss de samtida teorierna om ekonomiskt självintresse och idéerna om rena ekonomiska relationer. Här är det relevant att förstå att det finns en socialistisk politisk grund. Det är nämligen under perioden 1923 och 1924 som Mauss är mest politiskt engagerad som socialist, vilket innebär att detta är en tid då han sökte kombinera sociologin med socialism (Fournier 2005:189; Graeber 2001: 156). Med detta sagt, vill jag hävda, var de etnografiska beskrivningarna om Nordvästkusten och Melanesien passande för utvecklingen av en ny socialistisk teori som sammanfogar dikotomier som frihet/tvång och generositet/egennytta. Mauss som i sina slutsatser skriver om en gyllene medelväg, menar att moralen i gåvogivningen balanserar mellan kommunism och de samtida egoistiska och individualistiska trenderna. Det är sålunda denna moraliska medelväg som Mauss uppmanar läsaren att följa (Mauss 1972:88f.).

Utefter en förståelse av Mauss uppfattning om relationen mellan teori och empiri, samt i förhållande till den intellektuella och politiska kontexten, blir det lättare att förstå hans lokala strategier i samband med de etnografiska beskrivningarna. Strategierna används för att visa på ett socialt kontrakt samtidigt som de hjälper honom att skissa en ny socialistisk teori att förhålla sig till i sin samtid.

\section{Några avslutande tankar om tystnad}

Med hjälp av Fardons teoretiska ramverk går det att påstå att Mauss återanalyser vilar på en tyst legitim grund eftersom de etnografiska beskrivningarna förefaller uppfattas som både teori- och kontextlösa. Att Boas ordnat sin etnografi utefter idén om historisk partikularism, och att Malinowski följer ett funktionalistiskt spår i sin beskrivning, verkar inte beröra Mauss nämnvärt. Att Mauss rör sig fritt mellan olika beskrivningar vittnar, i linje med Fardons argument, om en kumulativ etnografisk uppfattning: något som även styrks av Evans-Pritchards hyllning. Detta innebär vidare att Mauss, i relation till Boas, trots sitt filologiska förhållningssätt, ersätter olika termer med egna begrepp. Som vi sett ovan har det även blivit klart att Mauss, i samband med bytesföremålens kraft, övertolkar material genom att tillskriva en del föremål „nya“ karakteristiska drag som inte återfinns i de ursprungliga etnografiska beskrivningarna. Inte sällan framställer han egna hypoteser från det empiriska materialet som gör det svårt för läsaren att följa med i resonemanget. Genom att Mauss utesluter en del viktig information för läsaren uppstår det bitvis en del diffusa argument. I relation till Malinowski kan vi se hur kulamaterialet till en början samspelar med Mauss Durkheimska arv. Detta samspel, mellan de båda antropologerna, transformeras emellertid senare 
till en polemik när Mauss går till angrepp gentemot den „rena gåvan“. Genom att Mauss i sin polemiska framtoning exkluderar tiden i den sociala relationen (dvs. om den är tillfällig eller permanent), samt utesluter individens emotionella aspekter, kan han argumentera för att den rena gåvan inte existerar. Här skall det dock understrykas att Malinowski senare ger Mauss rätt i sin kritik. Frågan här är varför Mauss gjorde allt detta? Det huvudsakliga argumentet är att Mauss i rollen som skrivbordsetnograf utgår från en färdig teoretisk föreställning - han tar sin utgångspunkt från ett deduktivt angreppssätt i konstruktionen av sin gåvoteori. Detta blir mer påtagligt när hans strategiska tillvägagångssätt inplaceras i ett historiskt, intellektuellt och politiskt sammanhang. På en teoretisk nivå är Gåvan ett svar till det samtida vetenskapliga intresset att söka efter samhällets sociala kontrakt. På en politisk nivå är gåvoteorin en ny socialistisk teori som följer en gyllene medelväg mellan kommunism och egoism/individualism. På ett övergripande plan går det att påstå att Mauss tystnad bygger på ett universalistiskt förhållningssätt där helheten står över delarna. Detta innebär att relationen mellan de tidigare antropologernas partikulära observations- och analystekniker och deras etnografiska beskrivningar förblir tyst i sammanhanget.

Vad kan vi då generellt lära oss om tystnad utifrån det ovan nämnda? Strävan efter att synliggöra tystnaden - de lokala strategierna - i den etnografiska beskrivningen förefaller bygga på ett upplysningsideal där antropologerna utgår från att ju mer de vet, desto bättre går det att kontrollera den antropologiska disciplinens öde. Som bekant finns det emellertid en inbyggd ambivalens i denna strävan. För samtidigt som antropologerna får bättre insikt om lokala strategier, som representerar det tysta, ökar tvivlet kring den etnografiska beskrivningen. I själva verket har vi här en strävan som hänger tätt samman med konflikten mellan tvivel och förtroende. Denna form av ambivalens kan betraktas som en grundläggande mekanism för de vitala och kreativa processer som driver den antropologiska disciplinen framåt. Med hänsyn till detta bör därför tystnadens inneboende ambivalens bejakas snarare än förkastas eller tämjas. Vad antropologerna emellertid bör hålla koll på är om den ,ena sidan“ börjar dominera den antropologiska tankeverksamheten såsom skede under den ,postmoderna eran“, då många antropologer började tvivla på det etnografiska projektet. Vad som blir av vikt att fundera över i sådana sammanhang är hur den samtida kontexten påverkar den ambivalens som finns i strävan efter att synliggöra tystnaden. 


\section{Note}

1. Detta kanske uppfattas vara logiskt med tanke på Durkheims projekt, som kraftigt influerade Mauss, handlade om att sociala fenomen inte kunde reduceras till psykologi. Men, faktum är att Mauss redan under 1920-talet hade en interdisciplinär kontakt med det psykologiska ämnet i syfte att sträva bortom Durkheims antagonism (Mauss 2006:77).

Søgeord: Marcel Mauss, Gåvan, teori, etnografi, lokala strategier, tystnad

\section{Litteratur}

Agar, Michael H.

$1986 \quad$ Speaking of Ethnography. Beverly Hills: Sage.

Boas, Franz

$1889 \quad 5^{\text {th }}$ Report: Report of the British Association for the Advancement of Science. London: Spottismoode and Co. New street square.

1909-1910 Tsimshian Mythology: $31^{\text {th }}$ Annual Report of the Bureau of American Ethnology. Washington: Government printing office.

1913-1914 Ethnology of the Kwakiutl: $35^{\text {th }}$ Annual Report of the Bureau of American Ethnology. Washington: Government printing office.

Carrier, James G.

1991 Gifts, Commodities, and Social Relations: A Maussian View of Exchange.

Sociological Forum 6(1):119-36.

Codere, Helen

1959 Understanding of the Kwakiutl. I: W. Goldschmidt (ed.): The Anthropology of Franz Boas: Essays on the Centennial of His Birth. Menasha, WI: American Anthropological Association.

Deleuze, Gilles

2004 Vecket: Leibniz \& barocken. Göteborg: Glänta.

Fardon, Richard (ed.)

1990 Localizing Strategies: Regional Traditions of Ethnographic Writing. Edinburgh: Scottish Academic Press.

Fournier, Marcel

2005 [1994] Marcel Mauss: A Biography. Princeton, N.J.: Princeton University Press.

Godelier, Maurice

1999 The Enigma of the Gift. Cambridge: Polity Press.

Graeber, David

2001 Toward an Anthropological Theory of Value: The False Coin of Our Own Dreams New York: Palgrave.

Hart, Keith

2007 Marcel Mauss: In Pursuit of the Whole. Comparative Studies in Society and History 49(2):1-13.

Lévi-Strauss, Claude

1987 Introduction to the Work of Marcel Mauss. London: Routledge \& Kegan Paul. 
Liep, John Press.

Lindberg, Christer

1997a Franz Boas (1858-1942) och utvecklingen av kulturbegreppet. I: C. Lindberg (ed.): Antropologiska porträtt 2. Lund: Sociologiska institutionen.

1997b Vetenskap eller spekulation? Lewis Henry Morgan (1818-1881). I: C. Lindberg (ed.): Antropologiska porträtt 2. Lund: Sociologiska institutionen.

Malinowski, Bronislaw

1922 Argonauts of the Western Pacific: An Account of Native Enterprise and Adventure in the Archipelagoes of Melanesian New Guinea. London: Routledge \& Kegan Paul.

1967 Brott och bruk i ett primitivt samhälle. Uppsala: Argos.

Mauss, Marcel

1972 [1925] Gåvan. Uppsala: Argos.

2006 Techniques, Technology and Civilization. Oxford: Berghahn Books.

Parry, Jonathan

1986 The Gift, the Indian Gift and the 'Indian Gift'. Royal Anthropological Institute of Great Britain and Ireland 21(3):453-73.

Sahlins, Marshall D.

1984 Stone Age Economics. London: Tavistock Publications.

Smith, Marian W.

1959 Boas' 'Natural History' Approach to Field Method. I: W. Goldschmidt (ed.): The Anthropology of Franz Boas: Essays on the Centennial of His Birth. Menasha, WI: American Anthropological Association.

Testart, Alain

1998 Uncertainties of the 'Obligation to Reciprocate': A Critique of Mauss. I: W. James \& N.J. Allen (ed.): Marcel Mauss: A Centenary Tribute. Oxford: Berghahn.

Trigger, Bruce G.

1993 Arkeologins idéhistoria. Stockholm/Stehag: Brutus Östlings bokförlag Symposion. 
